\title{
STANDARD OF CARE AND LIABILITY OF PUBLIC PROCUREMENT OFFICIALS: BLESSING OR CURSE?
}

\author{
Allison Megan Anthony \\ $B A$ LLB LLM LLD \\ Senior Lecturer, Department of Public, \\ Constitutional and International Law, University \\ of South Africa
}

\section{SUMMARY}

Section 217 of the Constitution provides that organs of state, when contracting for goods or services, should do so in accordance with a system that is fair, equitable, transparent, competitive and cost-effective. Therefore, public procurement officials acting on behalf of such organs of state should act in terms of these principles. When their conduct falls foul of section 217 , it may be declared unlawful by a court of law. In the recent past, there have been countless reports of unexplained corruption, theft and fraud committed by public officials, especially in the public procurement sector. Consequently, the legislature, by enacting legislation (specifically the new Public Audit Amendment Act 5 of 2018), and the judiciary, by imposing cost orders, have started holding public procurement officials personally liable for unlawful conduct. This article examines the latest developments in this area of law, including case law and recent legislative amendments, and asks the question whether the standard of care and liability of public procurement officials has increased because of these developments.

\section{$1 \quad$ INTRODUCTION}

As of late, the liability of public procurement officials has come under the spotlight, particularly from a legal perspective, based on a recent court judgment that created much discontent among officials. In line with this, public procurement officials, during various procurement conferences, are reported to have become somewhat cautious when it comes to decision making in public procurement processes. This extends not only to decision makers but also to those who serve on bid committees. As a result, it has become necessary to analyse the law - specifically new case law and legislative changes pertaining to the liability of public procurement officials. 
Public procurement is provided for in section 217 of the Constitution. ${ }^{1}$ Section 217 provides that, when organs of state contract for goods or services, they should do so in accordance with a system that is fair, equitable, transparent, competitive and cost-effective. ${ }^{2}$ This constitutes the standard against which the actions of public procurement officials must be measured. The phrase "contract for" in section $217(1)$ has been interpreted to mean not only to acquire or buy but also to sell and lease. ${ }^{3}$ When organs of state buy, sell, lease or hire goods or services, they must comply with section $217(1)$ of the Constitution. This article examines a recent judgment and legislative provisions in order to determine whether the standard of care expected of public procurement officials has, based on these provisions, been raised so as to increase the liability of these officials, and what the impact of this may be.

\section{CASE LAW - Westwood Insurance Brokers (Pty) Ltd v Ethekwini Municipality ${ }^{4}$}

\section{Facts of the judgment}

In this matter, Ethekwini Municipality advertised a call for tenders for the provision of water loss insurance. The tender was awarded to NC South West Brokers CC (South West), which, it was later established, provided professional indemnity insurance and not water loss insurance. At the time of the award of the tender, Westwood was the tenderer providing water loss services to the municipality; it was to be replaced by South West once the new contract came into operation. More than a month after the award of the new tender, a letter was mailed to the unsuccessful tenderers to inform them that South West was the successful tenderer. Westwood subsequently objected to the award and also to the delay in receiving the notification, which resulted in the expiry of the time for lodging an appeal against the award. The municipality informed Westwood that it had already entered into a contract with South West and that the contract was due to start within a few months. Soon after receiving this information, Westwood launched an application to interdict implementation of the contract, pending an application for review of the decision to award the contract to South West.

\section{Issues in dispute}

The issue the court had to decide in this matter was whether the tender submitted by South West complied with clause 3 of the tender specifications, which provided:

Constitution of the Republic of South Africa, 1996 (the Constitution).

See s 217(1).

Bolton The Law of Government Procurement in South Africa (2007) 67.

(8221/16) [2016] ZAKZDHC 46 (8 December 2016). 
"Registration offers underwritten by insurance companies licenced to operate in South Africa will only be considered. A letter of undertaking from the insurance company must accompany the offer.

The underwriter must be registered with the Financial Services Board (FSB)."

It was alleged that South West did not comply with the above specification in that it was not underwritten by an insurance company licensed to operate in South Africa and that its underwriter was not registered with the FSB. ${ }^{5}$

\section{Arguments proffered}

It was argued on behalf of the municipality that section 217 of the Constitution was not applicable to this matter since the word "procurement" should be interpreted to refer only to those transactions where the State buys goods and services, and not to instances where an organ of state provides services, as in this matter. ${ }^{6}$ However, the court noted that the municipality's own documentation confirmed that the legislation applicable to section 217 of the Constitution would apply to this tender. It thus had to act in accordance with procurement provisions of the Constitution and the applicable legislation. The municipality further alleged that it was not paying for the services advertised and that it was merely providing the platform from which a broker could contract with water users or the public. It was later apparent that the municipality would in fact charge a fee of 8,5 per cent of the premiums collected from residents to cover its administrative costs. ${ }^{7}$ In terms of the agreement with South West, the municipality would collect the premiums on behalf of South West. Therefore, both the municipality and South West would benefit financially from the contract. ${ }^{8}$

\section{Judgment}

The court found that "as a matter of law, fact and the letter and spirit of $s 217$ of the Constitution", procurement law was applicable to this matter. ${ }^{9}$ Based on the facts, the court held that the award of the tender to South West was indeed questionable. ${ }^{10}$ Nonetheless, the municipality contended that based on the separation of powers principle, the court should not itself appoint a service provider as a remedy. ${ }^{11}$ To this, the court responded that although

$$
\begin{aligned}
& \text { Par } 12 . \\
& \text { Par } 13 . \\
& \text { Par } 15 . \\
& \text { lbid. } \\
& \text { Par } 19 . \\
& \text { Par } 28 .
\end{aligned}
$$

11 Par 29. This remedy is known as substitution. It is an extraordinary remedy used only in exceptional cases. Instances in which a court may consider substitution include where the end result is a foregone conclusion, where it would be a waste of time to remit the decision to the original decision maker, where further delay will result in unjustifiable prejudice to the applicant, and where the original decision maker has displayed bias or incompetence to such an extent that it would be unfair to expect the applicant to submit to its jurisdiction again. See Hoexter Administrative Law in South Africa 2ed (2012) 552-553. 
authorities are firmly set against substitution as a remedy, a court will be permitted to do so in very clear cases, or if the organ of state involved has been so biased or incompetent in its actions that it would be unfair to expect the aggrieved party to submit to the same authority again. ${ }^{12}$ In such a case, substitution would be just and equitable, as required by section 172 of the Constitution. $^{13}$

The court held that simply to set aside the tender award to South West would mean that there would be no insurer underwriting the risk of water loss through possible leaks. The majority of victims of this wrongly awarded tender would be the residents and ratepayers whose interests were not represented in this matter and the consequences of the unconstitutional conduct of public officials cannot rest upon the shoulders of the residents. ${ }^{14}$ The court also cannot be "held to ransom by deference to the principle of separation of powers principle when institutions violate their powers". ${ }^{15}$ Therefore, substitution was a just and equitable remedy. In addition, the prejudice to ratepayers would not be remedied without determining who should indemnify the municipality for all costs incurred in this matter, which, in the court's opinion, constituted wasteful litigation. ${ }^{16}$ The court then held:

"The courts have long been sounding the caution that public officials must be held accountable for acting unconstitutionally, unlawfully, dishonourably and unethically. Importantly, care must also be taken not to trench on the rights of potential transgressors, especially the rights to due process and fairness ...To apply the general rule that costs should follow the result would lead to taxpayers carrying the costs ultimately. They are unsuspecting victims of the illegalities perpetrated by officials appointed to serve their best interests.

As a result, the court held that any person who participated in support of awarding the contract to South West must show cause why they should not be held liable for all costs jointly or severally, the one paying the others to be absolved.

12 Par 30. To this end, the court held at par 31 that "the inefficiencies of some officials of Ethekwini involved in this tender and their unexplained and unjustified preference for South West were deterrents to deferring to Ethekwini to correct the process and make a fresh appointment. Whatever the reasons for their decisions ... the lack of transparency and accountability of public officials and persons performing public duty under the glare of the Constitution was decisive."

13 S 172 provides that upon declaring an administrative action to be unlawful, a court may provide a remedy that is just and equitable.

14 Par 35

15 Ibid.

16 See par 36 and 67.

17 Par 61. The illegal behaviour of the officials essentially lay in the advertisement of a tender for water loss insurance, yet awarding the contract to a tenderer who offered professional indemnity insurance. The unlawful award of the contract was thus blatant. The court held at par 7 that the officials should have known the difference and that "[s]ubstituting the one for the other calls into question not only the competence but possibly also the integrity of those who accepted the quotation for professional indemnity insurance instead of underwriting insurance for water leaks." This was exacerbated by the failure of the municipality to show cause for these actions despite being given ample opportunity by the court to do so. This, coupled with the municipality's disregard of legal advice led to the court's inference of deliberate action. 


\section{Application for leave to appeal ${ }^{18}$}

In the application for leave to appeal, it was alleged that the court a quo erred or misdirected itself in assuming jurisdiction or the power to grant the orders it gave mero motu and against parties who were not joined in the matter. The court then traversed various previous judgments in which cost orders were made against public officials. ${ }^{19}$ It held that the judgments have over time called for public officials to be held personally liable for costs in the case of grossly irregular behaviour. However, this cannot be the case where an official has made a bona fide mistake. The court then relied on MEC for Health, Gauteng $v$ Lushaba, $^{20}$ in which the Constitutional Court held that holding public officials personally liable for costs incurred is possible, provided they have adequate notice to make representations (author's own emphasis). The court found its final authority in the recent controversial Black Sash matter. ${ }^{21}$

The court, in the Westwood leave to appeal application, held:

"As public officials become more brazen, the courts are emboldened commensurately to respond naturally, intuitively and pragmatically to do justice. Quite simply, if society was not afflicted so detrimentally by those exercising public power, there would never be a need for the courts to order costs de bonis propriis against them ... A prescription to prevent courts from ordering costs de bonis propriis against public officials, irrespective of whether they are parties to the litigation or not, would serve no purpose but to blind the court to its constitutionally entrenched oversight function. That would be untenable."

The court held that what was different in this matter compared to previous judgments is that the court heard only one party's view after Westwood withdrew from the proceedings. Therefore, acting mero motu was unavoidable and if it did not act, the court would unjustifiably be saddling the public with costs. ${ }^{23}$ Moreover, none of the parties made representations as to why the public should be responsible for the costs, which would ordinarily have been the case in such matters. Furthermore, the municipality was granted numerous opportunities to make representations as to why an adverse costs order should not be made against its officials.

A second argument made in the application for leave to appeal was that the court unduly disregarded the separation of powers doctrine in awarding the costs order. To this end, the court relied on section 172 of the

18 Westwood Insurance Brokers (Pty) Ltd v Ethekwini Municipality (8221/16) [2017] ZAKZDHC 29 (31 July 2017)

19 See for e.g., Mitchell $v$ Mossel Bay Liquor Licensing Board 1954 (1) SA 398 (C): Coetzeestroom Estate and G.M. Co. v Registrar of Deeds 1902 TS 216; Deneysville Estates Ltd v Surveyor-General 1951 (2) SA 65 (C); Omnia Fertilizer Ltd v Competition Commission; In re Competition Commission v Sasol Chemical Industries (Pty) Ltd [2008] JOL 22197 (CT); Mlatsheni v Road Accident Fund 2009 (2) SA 401 (E).

202017 (1) SA 106 (CC).

21 Black Sash Trust v Minister of Social Development (Freedom Under Law Intervening) 2017 (3) SA 335 (CC).

22 Par 19.

23 Par 21. 
Constitution, which enjoins the court to provide remedies that are just and equitable. It also emphasised that the issue of costs orders is entirely within the discretion of the court. ${ }^{24}$ Furthermore, if the costs were not paid by the officials, it would naturally have to be borne by the public. Based on this, it would have been unjust and inequitable for the court to hold the public responsible for costs incurred by the grossly irregular behaviour of public officials. The court then held that had the municipality indicated that it would hold its public officials accountable for their actions as required by the law, it may have exercised its discretion differently. The municipality was also not historically known to act against officials who disregarded or contravened procurement rules. ${ }^{25}$ Moreover, the municipality had a poor track record in receiving qualified audits and incurring irregular expenditure based on deviations from procurement rules that were either not approved or not justifiable. ${ }^{26}$

The third ground of appeal was that the court erred or misdirected itself by failing to join the employees before ordering them to pay costs. To this end, the court again relied on the Lushaba judgment and held that the "Constitutional Court did not stipulate joinder as the exclusive means of providing an opportunity to be heard" ${ }^{27}$ To hold that the court should have joined the parties before making the costs order would be to prefer form over substance ${ }^{28}$ What worsened Ethekwini's case is the fact that it conceded defeat without providing reasons for the unlawful actions of its officials. According to the court, representations by Ethekwini could have involved identifying the persons involved in the award or those who intimidated others to make the unlawful award. Alternatively, an indication of a possibly bona fide mistake made by an official could have been provided. ${ }^{29}$ These representations were requested in order to assist the court in resolving the matter. However, none were forthcoming. Therefore, in requesting representations, the court acted appropriately before imposing the costs order. Prior joinder was thus not necessary.

The fourth ground of appeal was that the court erred or misdirected itself by failing to establish bad faith or dishonesty on the part of the employees before ordering them to pay costs. In response to this ground, the court relied on its request for representations by the parties and once again emphasised their failure to do so. Based on the information at hand, the court had no choice but to award the costs de bonis propriis on the municipality's refusal to account for an irrational and unlawful decision. The court held that a refusal to account is simply unconstitutiona ${ }^{30}$ and that " $[\mathrm{t}] \mathrm{he}$

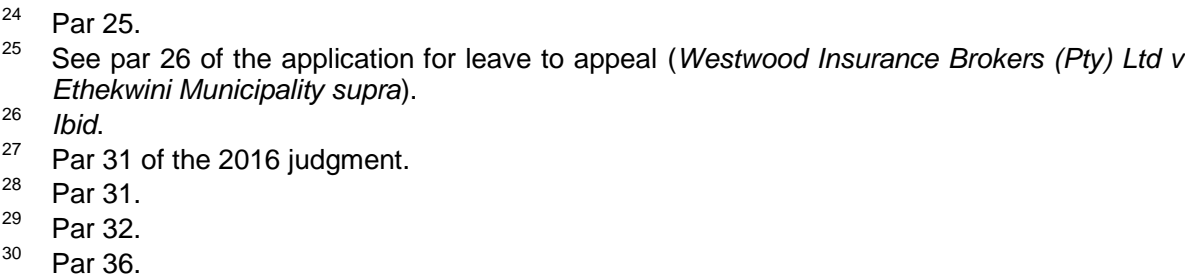


onus rests on those refusing to account to show why they should not be mulcted with costs or penalised in some other way." ${ }^{31}$

The fifth and last ground of appeal was that the court failed to consider that its order would terrorise and/or paralyse employees into not performing their duties for fear that every error whether significant or not would be sanctioned. The court held that the punishment should always be commensurate to the act performed. Therefore, a small error would be sanctioned with a lesser punishment. However, when the error is a failure to account despite a constitutional obligation to do so and when the consequences are dire, the error is not insignificant. The court simply answered that honest employees need not suffer paralysis. Where genuine errors are made, an employee could escape liability but only if they account fully as to how the error occurred. ${ }^{32}$ "Without accountability, transparency and remorse, no reprieve is permissible is a basic tenet of our natural law."

\section{COMMENTARY}

This judgment highlights two tenets of public procurement law accountability and transparency. As noted above, public procurement in South Africa is regulated by section 217 of the Constitution, which provides that when organs of state contract for goods or services, they should do so in accordance with a system that is fair, equitable, transparent, competitive and cost-effective. ${ }^{34}$ Public procurement has also been held by our courts to be a form of administrative law, ${ }^{35}$ and therefore section 33 of the Constitution is applicable. ${ }^{36}$ This includes provision for the right to reasons for administrative actions and the right to information. The court in Westwood held that no reasons were provided for the actions taken, and neither was any information provided as to why the unlawful award was made. Section $5(3)$ of the Promotion of Administrative Justice Act ${ }^{37}$ provides that if an administrator fails to provide adequate reasons for administrative action, a court must, subject to subsection $(4)^{38}$ and where there is no proof to the contrary, presume that the administrative action was taken without good reason (author's own emphasis). Therefore, the court's adverse inference (made based on the lack of information or presentations by the municipality's officials) is legally permissible. Although the judgment had far-reaching consequences for the officials involved, it serves as a warning to public

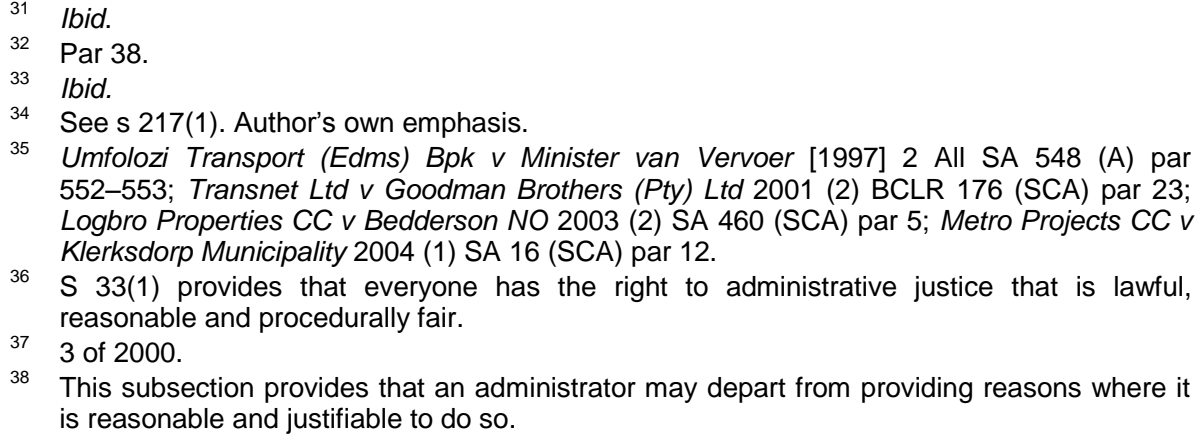
552-553; Transnet Ltd v Goodman Brothers (Pty) Ltd 2001 (2) BCLR 176 (SCA) par 23; Logbro Properties CC v Bedderson NO 2003 (2) SA 460 (SCA) par 5; Metro Projects CC v Klerksdorp Municipality 2004 (1) SA 16 (SCA) par 12.

$36 \mathrm{~S} 33(1)$ provides that everyone has the right to administrative justice that is lawful, reasonable and procedurally fair.

373 of 2000.

38 This subsection provides that an administrator may depart from providing reasons where it is reasonable and justifiable to do so. 
officials not to take lightly their mandate to act in terms of public procurement rules.

An interesting factor mentioned by the court was the municipality's track record of not holding accountable those officials who act unlawfully. It also referred to the municipality's contribution to irregular expenditure, based on unjustified deviations from procurement rules indicating the municipality's blatant disregard for these rules. The court further emphasised an important factor, which is the interest of the public. Where public officials have in the past disregarded procurement rules, the organ of state involved was held responsible for the costs incurred by the innocent tenderer. However, the court pointed out that this means those actually paying the costs are the taxpayers and that it serves no purpose to burden the public with costs incurred by negligent officials or those who wilfully act unlawfully. The court was further correct in holding that officials who make genuine mistakes could escape liability as not every administrative glitch should be met with judicial sanction. ${ }^{39}$ In this matter, the municipality not only acted unlawfully but conceded that it had done so. In addition, it did not provide any reasons for its actions and as such it can be inferred that it acted wilfully. The standard of care for public officials is thus not raised by this judgment. Public officials have always been obliged to act in good faith and transparently, and to account to the public. ${ }^{40}$ The fear among public officials that some may be sanctioned for any mistake made is thus not justified. Such adverse costs orders will only be made in the case of grossly irregular behaviour.

\section{4}

\section{LEGISLATION}

\section{Public Audit Amendment Act ${ }^{41}$}

During 2018, the Public Audit Amendment Act ${ }^{42}$ (Amendment Act) amended section 5 of the Public Audit $\mathrm{Act}^{43}$ with a provision that reads:

"The Auditor-General may, as prescribed, refer any suspected material irregularity identified during an audit performed under this Act to a relevant public body for investigation, and the relevant public body must keep the Auditor-General informed of the progress and the final outcome of the investigation."

A material irregularity is then defined as:

39 Moseme Road Construction CC v King Civil Engineering Contractors (Pty) Ltd [2010] 3 All SA 549 (SCA) par 21.

40 See $\mathrm{S} 195$ of the Constitution which provides for the basic values and principles for the public administration under which public procurement officials resort. The section requires that such officials act in accordance with a high standard of professional ethics with efficient, economic and effective use of resources. The section further importantly provides that the public administration must be accountable and transparency must be fostered. These principles must be promoted in national legislation which has been done in the Public Finance Management Act (PFMA) 1 of 1999 and the Local Government: Municipal Finance Management Act (MFMA) 56 of 2003.

415 of 2018.

42 Published in GG 42045 of 2018-11-20.

4325 of 2004. 
"[A]ny non-compliance with, or contravention of, legislation, fraud, theft or breach of a fiduciary duty identified during an audit performed under this Act that resulted in or is likely to result in material financial loss, the misuse or loss of a material public resource or substantial harm to a public sector institution or the general public".

Since this amendment has come into operation, the concern exists that the new section raises the standard of care expected not only of supply chain management practitioners, but of public sector officials in general. The objectives of the 2004 Public Audit Act are to give effect to the Constitution, to provide for auditing of public institutions, to provide for an oversight mechanism and to advise the National Assembly. The objectives of the Amendment Act are currently much stronger and more direct. Some of its intentions are to provide for certainty regarding the discretion of the AuditorGeneral and its actions, to undertake performance audits, to provide the Auditor-General with the power to refer material irregularities to the correct institution for investigation, to empower the Auditor-General to take appropriate remedial action and to address overspending in public institutions. This initiative can be commended as it recognises bad performance among public officials in the past, overspending, misuse of funds, lack of accountability and lack of enforcement of rules. The section above gives the Auditor-General the discretion to act against public officials by referring material irregularities to the relevant authority, including the National Director of Public Prosecutions. Public officials may thus be at greater risk of criminal liability since a procedure for addressing unlawful behaviour has now been provided for in legislation.

However, the directory nature of the wording of the section, seen in the word "may", indicates a mere discretion on the part of the Auditor-General, which may or may not be exercised in a given situation. Regulation 4(1) of the Investigations and Special Audits Regulations to the Amendment Act ${ }^{44}$ confirm this by providing that for purposes of section $5(1)(d)$ of the Act, the Auditor-General must in exercising his discretion carry out a special audit. ${ }^{45}$ The same wording is found in Regulation 4(1) of the Material Irregularity Regulations to the Act. ${ }^{46}$ Moreover, actions such as fraud, theft or breach of a fiduciary duty may in any event lead to criminal charges. This was the case even before the Amendment Act was passed. These actions all involve an element of intent, which aligns with the Westwood judgment in which the court held the officials personally liable based on intentional or wilful actions.

Although the Amendment Act does not impose new duties on public officials, it does create some uncertainty. The use of words such as "is likely to" may need to be interpreted by a court in order to determine when it would be likely for the material irregularity to cause material financial loss or harm. The words "substantial harm" would also need to be interpreted to determine when harm is substantial since all loss, fraud or theft is harmful to the public purse. The above regulations assist in this regard by providing guidance on 
the factors to be taken into account when deciding whether a material irregularity has occurred. These include whether the irregularity may be subject to investigation by another public body or a court, whether that body is in a better position to undertake the investigation, whether the actions taken by the accounting authority were appropriate and timeous, and the actual or suspected involvement of the accounting officer or any other political office bearers in actions that may constitute a material irregularity. ${ }^{47}$ Factors such as these could thus indicate whether the action in question "is likely to" result in loss, misuse or harm. The same factors would thus be relevant in determining when "substantial harm" may ensue. There is thus no raised standard of care for supply chain officials. The new provisions merely grant the Auditor-General the discretion to hold officials accountable in the case of unlawful actions. By implication, honest or genuine mistakes could and should still be treated with the appropriate remedy short of liability in terms of the new Act.

\section{National Treasury Instruction Note 3 of $2016 / 2017^{48}$}

The above Instruction Note was published with the title "Prevention and Combating Abuse in the Supply Chain Management System". The purpose of the Instruction Note is to set rules to prevent abuse of the public procurement process (author's own emphasis). The Oxford Dictionary defines "abuse" as using something to bad effect or for a bad purpose or misuse. ${ }^{49}$ The conduct sought to be prevented by the Instruction Note is thus that which involves intent or mala fides. Examples of the type of behaviour the Instruction Note seeks to uproot would therefore be fraud or theft. Point 10 of the Instruction Note provides that "[e]very member of the Bid Committee is jointly and severally liable for the improper evaluation and adjudication of the bid." The definition of "improper" in turn is to act contrary to accepted standards, especially of morality and honesty. ${ }^{50}$ As in the Westwood case, this Instruction Note should be interpreted within its context, which is to prevent wilful, unlawful, intentional behaviour to defraud or steal from the public purse. ${ }^{51}$ As noted, the word "improper" means to act contrary to accepted standards such as those in section 217 . Thus meaning to act unfairly, inequitably, not transparently, uncompetitively or having ill regard for the achievement of cost-effectiveness and instead overrunning costs or causing fruitless and wasteful expenditure. ${ }^{52}$ This is further

47 Regulation 4(1)(a)-(d) of the Material Irregularity Regulations.

48 It should be noted that Instruction Notes published by National Treasury are permitted by s 76 of the PFMA.

49 An alternative definition provided is "use or treat in such a way as to cause damage or harm".

50 Oxford English Dictionary 2ed (2004).

51 Such an interpretation would be in line with the judgment in Natal Joint Municipal Pension Fund v Endumeni Municipality 2012 (4) SA 593 (SCA), in which the court held that a contextual interpretation should be given to legal documents, having regard to the purpose of the provisions and the background to the document. See par 18.

52 Bolton notes that even though not all five principles will be applicable at the same time, they act as a whole and must be complied with throughout the procurement process albeit at 
evidenced by the wording of the Instruction Note, which includes "financial misconduct", "allegations of a criminal nature", "allegations of abuse" and the provision made for the investigation of complaints and remedial action, much like the Public Audit Amendment Act aims to achieve. Therefore, again, no raised standard of care is expected from procurement officials in terms of the Instruction Note. As in the case of Westwood and the Amendment Act, these initiatives merely add teeth to the requirements that public procurement officials must not contravene legislative (and ultimately constitutional) provisions - by authorising remedial steps where such behaviour has occurred.

\section{STANDARD OF CARE FOR PUBLIC PROCUREMENT OFFICIALS AT COMMON LAW}

At common law, there is no law regulating the conduct or liability of public procurement officials specifically. The ordinary laws of delict and criminal law thus apply. This means that for an official to be guilty of a delict or wrongful act, the five elements of a delict - namely conduct, wrongfulness, fault (both intent and negligence), causation and damage have to be met. ${ }^{53}$

In the case of a procurement contract, the agreement concluded is between the procuring organ of state and the supplier; therefore, only the organ of state (as a state institution) would incur liability. Individual officials are involved during the procurement phase of the process when no contract has yet been concluded. Any liability for this procurement phase would thus result from administrative law based on the grounds of review in the Promotion of Administrative Justice Act ${ }^{54}$ or under the principle of legality under the Constitution.

When it comes to criminal liability, a public procurement official would be criminally liable for acts that are punishable under criminal law such as fraud, theft or corruption. The Public Audit Amendment Act thus creates an additional avenue for liability by providing specifically for the conduct of public officials. The same argument is applicable to the Instruction Note, which provides for express joint and several liability for procurement officials.

To this end, a distinction should be made between "standard of care" and "liability" as applied to officials. The Oxford English Dictionary defines a standard as "a level of quality or attainment; a required or agreed level of quality or attainment". In this context, the definition aptly describes the level of quality in the behaviour or conduct of public procurement officials. Liability, on the other hand, is defined as "the state of being legally responsible for something; a thing for which someone is responsible, especially an amount of money owed".

different times. Therefore, non-compliance with even just one of the principles will constitute conduct that falls foul of section 217 of the Constitution. See Bolton The Law of Government Procurement in South Africa 56.

53 See Neethling, Potgieter and Visser Law of Delict 5ed (2006).

543 of 2000 . 
Although liability under the Amendment Act may have grave consequences for an official (such as loss of employment for an accounting officer because a criminal record means he or she may not hold the position), the act of creating specific liability for public procurement officials can be commended. This is because public officials who act on behalf of and in the public interest in the course of expending public funds should not take the standard of care (in other words, the quality of conduct) expected of them lightly. This level of conduct is mandated by section 195 of the Constitution, which demands ethical and efficient conduct from officials. This is especially important in the current political climate in South Africa where an astounding number of public officials have been found to have unlawfully benefitted from the public purse. ${ }^{55}$

\section{STANDARD OF CARE FOR PUBLIC PROCUREMENT OFFICIALS INTERNATIONALLY}

The 2011 United Nations Commission on International Trade Law (UNCITRAL) Model Law on Public Procurement regulates public procurement for those states that are party to the United Nations. Although South Africa is not a party to UNCITRAL, it is still important for the country to align its laws and policies with international documents in order to be globally recognised and competitive. As De la Harpe states:

"To be able to compete in the global market and to ensure economic growth, South Africa needs a procurement regime that can balance the internationally accepted objectives for public procurement with its need to address socioeconomic objectives, including the need to rectify the imbalances created by apartheid."

Article 26 of the Model Law states that a code of conduct for public officials must be enacted. It should address conflicts of interest, screening procedures and training requirements. In South Africa, the National Treasury has published a code of conduct ${ }^{57}$ that is applicable to all public procurement officials in all spheres of government. ${ }^{58}$ The Code addresses the broad principles of conflicts of interest, accountability, openness, confidentiality, rules for tender evaluation and adjudication teams and combative practices. It thus seems generally to comply with the requirements of Article 26. The Code of Conduct for Public Servants published in terms of the Public Services Act ${ }^{59}$ provides for general principles of conduct for all public servants. Similar principles to these are echoed in the Act, thereby legislating liability for acts that would make officials liable at common law. The Amendment Act also makes the actions for which liability could be

55 See for e.g., the Public Protector's Report 6 of 2016/17 entitled "State Capture", which implicates numerous public officials in corrupt public procurement dealings.

56 De la Harpe Public Procurement Law: A Comparative Analysis (Unpublished doctoral thesis, University of South Africa) 20097.

57 Known as the Code of Conduct for supply chain management practitioners in Practice Note Number SCM 4 of 2003.

58 This means national, provincial and local government.

59103 of 1994. 
incurred more specific in referring to a "material irregularity". It should be emphasised that, in the case of wilful conduct or gross negligence, liability in terms of the Amendment Act, based on the interpretation above, should ensue. In other words, an element of intent should be present.

Internationally, the Chartered Institute of Procurement and Supply (CIPS) is a body that provides the minimum qualifications for public procurement officials. ${ }^{60}$ It has a code of conduct in terms of which officials must act. Since CIPS is an international body, the code of conduct is applicable to all public procurement officials who are members of the Institute. The Code further indicates that the laws of an official's home country must be obeyed. The requirements of the Code are similar to those in the South African codes of conduct, therefore creating an alignment between South African and international requirements for the conduct of public procurement officials. International comparisons show that the provision for "material irregularity" in the Amendment Act is thus not overly strict. In fact, the issue of materiality is not one that is strange to the public procurement field. When deciding whether a tenderer has complied with tender conditions or specifications, the deviance from the conditions must be material in order to constitute a legitimate deviation worthy of the tenderer's disqualification from the tender process. ${ }^{61}$ Furthermore, when negotiation generally takes place between an organ of state and a potential supplier in public procurement, the resultant terms of the contract cannot "materially" differ from the tender specifications. Therefore, a requirement that a mistake made by a public procurement official be a "material irregularity" is at least legally speaking, not misplaced.

\section{CONCLUSION}

Although it may prima facie appear that the standard of care for public procurement officials has been raised with the recent legislation and case law, this is not the case. Upon interpretation of the judgment, the legislation and the Instruction Note, it is clear that the purpose of what seems to be a new approach to the actions of procurement officials is in fact the legislature, executive and judiciary acting upon the unlawful acts of officials who have been personally and unlawfully benefiting from the public purse. Our courts have held that the time has come to hold public procurement officials personally liable for unlawful actions. The Public Audit Amendment Act, the above Regulations and the National Treasury Instruction Note ${ }^{62}$ simply create a framework for combating abuse and unlawful conduct in the public procurement system. This is no different from what has always been required of public procurement officials in terms of the common law and other general legislation such as the Prevention of Organised Crime Act. ${ }^{63}$ Although the courts may have to assist in interpreting some of the wording included in these documents, the newly promulgated regulations and the intention and purpose of the documents as explained above provide some

\footnotetext{
See www.cips.org.

Bolton The Law of Government Procurement 182.

3 of 2016/17 Preventing and Combating Abuse in the Supply Chain Management System. 121 of 1998.
} 
explanation as to what the wording could mean. This legislation will go a long way in protecting the public purse from theft and corruption.

While the standard of conduct expected of public officials may not have changed, it is fair to conclude that the liability of public procurement officials has increased. In other words, what is expected of procurement officials in terms of their conduct has not changed, but the various ways in which they can be held liable for conduct falling short of what is expected have expanded. This is due to the additional avenue for liability provided for in the Public Audit Amendment Act, most likely brought about by an increase in corruption among public officials. This amendment can thus be commended. 